\title{
Reshaping Canada's Broadcasting Act: Solutions in Search of a Problem?
}

\author{
Michael Geist
}

Abstract: The Canadian government introduced much-anticipated reforms to Canada's national broadcasting legislation in November 2020. The legislation - Bill C-10 - was framed as a long-needed update to rules that had not been updated in decades and failed to account for the emergence of Internet streaming services such as Netflix and Disney+ that had become enormously popular with Canadian subscribers. The bill emerged as one of the most controversial political issues in Canada, highlighting the challenges of regulating Internet services. While the public is broadly supportive of new regulations to address concerns about powerful Internet companies, the Canadian experience suggests there are concerns about the implications for freedom of expression, over-broad regulation, competition, and consumer costs.

Keywords: Broadcasting, Internet, Internet streaming, freedom of expression, culture, Netflix, Canada, Bill C-10, Social Media

\section{Chapter 1. Introduction}

The Canadian government introduced much-anticipated reforms to Canada's national broadcasting legislation in November $2020.0^{1}$ The legislation - Bill C-10 - was framed as a long-needed update to rules that had not been updated in decades and failed to account for the emergence of Internet streaming services such as Netflix and Disney+ that had become enormously popular with Canadian subscribers. The initial response to the bill was largely positive, with support from Canadian creator groups and

1 House of Commons of Canada, An Act to amend the Broadcasting Act and to make consequential amendments to other Acts, Bill C-10, 2nd sess, introduced in House November 3, 2020, https://www.parl.ca/LegisInfo/BillDetails.aspx?Language=E\&bil IId $=10926636$. 
indifference from much of the Canadian public. Yet months later, the bill was among the most controversial political issues in Canada, with political parties devoting days to debate it in the House of Commons, thousands signing petitions to protest the bill, and the government resorting to rarely used parliamentary maneuvers in order to shepherd the bill toward a final vote.

The battle over Bill C-10 highlights the challenges of regulating Internet services. While the public is broadly supportive of new regulations to address concerns about powerful Internet companies, ${ }^{2}$ there are clearly concerns about the implications for freedom of expression, over-broad regulation, competition, and consumer costs. As a result, government proposals that enjoy support within the narrow confines of the cultural community may face noisy opposition from the broader public.

This chapter examines the Canadian legislative experience with crafting Internet rules that rely primarily on broadcasting reform. The chapter begins by highlighting the decades-long policy process that included an initial exemption for Internet services, the consistent demands that those early policies be revisited, and the foundation for Bill C-10. The chapter critiques many aspects of the bill, noting that many policy issues are more complex than simply pointing to the need for a "level playing field" or bringing Internet companies into a national regulatory framework. Indeed, the Canadian experience provides a cautionary tale on Internet regulation and points to the need to rethink whether conventional broadcast legislation is the optimal regulatory model.

\section{Chapter 2. The Long Road to Internet Regulation}

The Canadian legal community became one of the first to consider the transformative effects of the Internet when the Canadian Radio-Television and Telecommunications Commission ("CRTC"), the country's lead regulator on broadcast and telecommunications matters, launched its new media hearings in the summer of $1998 .^{3}$ Although the Canadian legal

2 See, e.g, The Strategic Counsel, A Report to CIRA (Toronto, Ottawa, Calgary, Houston: The Strategic Counsel, 2021), https:/www.cira.ca/sites/default/files/2021 -05/CIRA_better-internet-report-2021.pdf.

3 Canadian Radio-television and Telecommunications Commission, Public Notice CRTC 1998-82 - New Media - Call for Comments (Ottawa: Canadian Radio-television and Telecommunications Commission, 1998), https://crtc.gc.ca/eng/archive/1 998/PB98-82.htm. 
and media communities expressed concern that the CRTC would use the hearings to establish new regulations to police the Internet, the final report yielded the opposite approach. ${ }^{4}$ In fact, the CRTC heeded the barrage of submissions from organizations imploring it to refrain from establishing new regulations. At that time, it accepted arguments regarding the perceived futility of traditional regulatory approaches and the benefits of providing new media companies with the regulatory space to develop unhindered.

After reviewing current Internet activity and the definition of "broadcasting," the CRTC held that the majority of services then-available on the Internet consisted predominantly of alphanumeric text, and therefore fell outside the scope of the Broadcasting Act and outside the Commission's jurisdiction. Moreover, new media services where the potential for user customization was significant (as with end-users who create their own uniquely tailored content) was also deemed not to be transmission of programs for reception by the public, and therefore fell outside the scope of the Broadcasting Act. ${ }^{5}$

The CRTC did conclude that some new media services fall under the Broadcasting Act's definitions of "program" and "broadcasting", however. Included was Internet content that consists only of "audio, video, a combination of audio and video, or other visual images including still images that do not consist predominantly of alphanumeric text." 6

Notwithstanding the application of the Broadcasting Act to certain forms of Internet broadcasting, the CRTC concluded that, for new media which falls under the definition of "broadcasting," regulation "will not contribute in a material manner to the implementation of the policy objectives set out in section 3(1) of the Act." ${ }^{17}$ Accordingly, pursuant to section 9(4) of the Broadcasting Act, an exemption order was proposed with respect to all new media undertakings that are providing broadcasting services over the Internet, in whole or in part, in Canada. ${ }^{8}$

4 Canadian Radio-television and Telecommunications Commission, "Public Notice CRTC 1999-84 - Report on New Media,” 1999, https:/crtc.gc.ca/eng/archive/1999/ PB99-84.htm.

5 Canadian Radio-television and Telecommunications Commission, "Public Notice".

6 Canadian Radio-television and Telecommunications Commission, "Public Notice".

7 Canadian Radio-television and Telecommunications Commission, "Public Notice".

8 Broadcasting Act, SC 1991, c 11, s 9(4). 
In 2009, 10 years after issuing its original exemption order, the Commission revisited the issue. ${ }^{9}$ After days of hearings and thousands of pages of submissions, the Commission again side-stepped the pressure to "do something," by maintaining its hands-off approach. It concluded that regulatory intervention would impede innovation. Indeed, the decision noted that "the Commission is of the view that parties advocating repeal of the exemption orders did not establish that licensing undertakings in the new media environment would contribute in a material manner to the implementation of the broadcasting policy set out in the Act."10

There was at least one very noteworthy change to the new media exemption, however. The CRTC was clearly troubled by allegations of undue preferences being granted by wireless providers and proposed amendments prohibiting such practices. ${ }^{11}$ Looking into the future, the Commission planned to review the decision within five years, initiate a reference at the Federal Court to sort out the status of ISPs within the Broadcasting Act, and extend the scope of new media monitoring by requiring "new media broadcasting undertakings to report details of their new media broadcasting activities, which may include broadcasting content usage and offerings, revenues and expenditures, at such time and in such form, as requested by the Commission." 12

At the time, Commissioner Tim Denton raised concerns about the content provisions of the Broadcasting Act in a powerful concurring opinion, concluding "the rights of Canadians to talk and communicate across the Internet are vastly too important to be subjected to a scheme of

9 Canadian Radio-television and Telecommunications Commission, Broadcasting Regulatory Policy CRTC 2009-329 (Ottawa: Canadian Radio-television and Telecommunications Commission, 2009), https://crtc.gc.ca/eng/archive/2009/2 009-329.pdf.

$10 \mathrm{Ibid}$, para 23.

11 Ibid. See, e.g., "The Commission proposes amendments to the New Media Exemption Order, prohibiting new media broadcasting undertakings from conferring an undue preference on themselves or another person, or subjecting any person to undue disadvantage. To provide guidance on the type of situation that could give rise to an undue preference in the new media environment, the Commission offers the example of a new media broadcasting undertaking engaged in programming distribution that acquires content from an affiliated programming undertaking either to the exclusion of non-affiliated programming undertakings or on more favourable terms or conditions than those applicable to non-affiliated programming undertakings."

12 Canadian Radio-television and Telecommunications Commission, Broadcasting Regulatory Policy. 
government licensing." ${ }^{13}$ Denton's comments foreshadowed much of the controversy over Bill C-10, which focused on the free speech implications of the bill.

In the years following, the rise of over-the-top (OTT) video providers such as Netflix was the cause of much consternation in the legacy broadcasting community. In 2011, a coalition of broadcasters, broadcast distributors (cable and satellite companies), and creators groups wrote to the CRTC to ask for a public consultation on foreign over-the-top services operating in Canada. ${ }^{14}$

The battle had been brewing for some time and what was particularly striking was how badly Canadian broadcasters and broadcast distributors understood the future impact of the Internet on their businesses. The prospect of the Internet becoming a substitute for conventional broadcast was not exactly a secret at the new media hearing in 2009. Yet, at the time, a representative from Shaw, a leading Canadian cable company, told the CRTC that the Internet was primarily for "self-generated content" and that it posed little threat to traditional cable broadcasters. ${ }^{15}$ Similarly, in 2009 Bell Media, Canada's largest communications company, told the Commission that OTT providers "may never become a substitute" to cable offerings. ${ }^{16}$ Despite their views that the Internet was no threat to smart business operators, Canadian broadcasters and broadcast distributors unanimously adopted the position that the CRTC should not establish new regulations for Internet-based broadcasting. ${ }^{17}$

13 Canadian Radio-television and Telecommunications Commission, Broadcasting Regulatory Policy, 12.

14 Canadian Radio-television and Telecommunications Commission, Broadcasting and Telecom Notice of Consultation CRTC 2011-344 (Ottawa: Canadian Radio-television and Telecommunications Commission, 2011), https://crtc.gc.ca/eng/archiv e/2011/2011-344.pdf.

15 Ibid.

16 Mirko Bibic, Transcript of Proceedings (Quebec: Canadian Radio-Television and Telecommunications Commission, 2009), https://crtc.gc.ca/eng/transcripts/2009/t b0311.html.

17 Canadian Radio-Television and Telecommunications Commission, Transcript of Proceedings, (Quebec, Canadian Radio-Television and Telecommunications Commission, February 26, 2009), https://crtc.gc.ca/eng/transcripts/2009/tb0226.ht $\mathrm{m}$; Transcript of Proceedings (Quebec: Canadian Radio-Television and Telecommunications Commission, March 10, 2009), https://crtc.gc.ca/eng/transcripts/2009 /tb0310.html; Transcript of Proceedings (Quebec: Canadian Radio-Television and Telecommunications Commission, March 11, 2009), https://crtc.gc.ca/eng/transcr ipts/2009/tb0311.html. 
A mere two years later, the perspective of the broadcasters shifted enormously. At a 2011 CRTC hearing, a representative from Bell Media called OTT providers "formidable competitors", and warned that Netflix would soon be able to "outbid Canadian broadcasters for exclusive program rights, both online and on television." 18 For its part, Shaw testified at a 2011 hearing, revising its 2009 assessment of the threat posed by OTT providers calling it "alarming" and the result of "major structural shifts in technology and rights exploitation that are permanently reshaping the global broadcast landscape". ${ }^{19}$ In the span of two years, legacy broadcasters had gone from the position of minimizing the potential effects of OTT providers on their businesses and calling on the Commission to refrain from regulating Internet broadcasting, to demanding immediate action on Netflix.

\section{Chapter 3. Change in Government, Change in Policy}

A change in governments in 2015 heralded a different approach to digital policy under the Liberal government. In September 2016, newly-appointed Canadian Heritage Minister Mélanie Joly launched a consultation on supporting Canadian content in a digital world. In the "pre-consultation" phase - an online poll of the public and stakeholders - there were hints at the policy challenges that would be faced by the new government. The poll received more than 10,000 responses with participants asked to identify the major barriers and challenges for Canadian content. The perspective of the public and industry stakeholders were strikingly different, with the public citing the challenges in finding and promoting content and the stakeholders seeking more money. ${ }^{20}$

Once the consultation started in earnest, it sparked renewed demands from industry stakeholders for more money from two main sources: unregulated Internet companies such as Netflix and the government. As

18 Kevin Crull, Transcript of Proceedings (Quebec: Canadian Radio-Television and Telecommunications Commission, April 4, 2011), https://crtc.gc.ca/eng/transcript s/2011/tb0404.html, para 136.

19 Paul Robertson, Transcript of Proceedings (Quebec: Canadian Radio-Television and Telecommunications Commission, April 6, 2011), https://crtc.gc.ca/eng/transcript s/2011/tb0604.html, para 2543.

20 Ipsos, What we heard across Canada: Canadian Culture in a Digital World, (Ottawa: Ipsos Public Affairs, 2017), https:/qcgn.ca/wp-content/uploads/2017/03/PCH-DigiCanCon-Consultation_Report-EN_low.pdf 
a starting position, the new consultation paper made it clear that not everything would be on the table. In fact, the consultation adopted several notable policies and sent some signals about future funding sources. First, it left little doubt that the government opposed new regulations for online video providers. ${ }^{21}$ Strong support for net neutrality and the avoidance of Internet regulation meant that proposals to exempt Canadian content from data caps or mandate certain rules for online providers were non-starters. Second, the government used the consultation to suggest where more money may come from and it was not Canadian tax dollars. ${ }^{22}$ By framing the consultation as an initiative that sat alongside already-announced funding, it seemed unlikely that more funding would be viewed as the answer. Indeed, the government was pretty clear about where it thought the money would come from: foreign markets.

Despite the direction provided in the consultation document, the government was less than clear in its communication on the issue of new taxes and regulations for online video providers. Joly appeared on a national television program after the policy launch and though she started by clearly stating that "there will be no new Netflix tax", the remainder of the interview was spent making the case for one. ${ }^{23}$ From the interview, it seemed that Joly subscribed to the view that there was a parallel between conventional broadcast and the Internet that invited a similar regulatory approach. Part of the rationale for broadcast regulation is that broadcast spectrum is scarce, therefore requiring licensing and regulation. By indicating that Internet services used a "large part of our spectrum", Joly made the case for treating Internet services as equivalent to broadcast. ${ }^{24}$

Following the completion of the consultation, the government announced in its 2017 budget that it planned to "review and modernize"

21 Canada, Department of Canadian Heritage, Canadian Content in a Digital World: Focusing the Conversation, (Ottawa: Department of Canadian Heritage, 2016), 7.

"To respect how Canadians want to consume and interact with digital content, we are committed to net neutrality - the idea that a public information network like the internet is most useful if all content, sites, and platforms are treated equally. The way forward is not attempting to regulate content on the Internet, but focusing on how to best support Canada's creators and cultural entrepreneurs in creating great content and in competing globally for both Canadian and international audiences."

22 Ibid, 4.

23 "GST on Netflix still a possibility as Liberals review cultural production," CTV News, October 16, 2016, https:/www.ctvnews.ca/politics/gst-on-netflix-still-a-possi bility-as-liberals-review-cultural-production-1.3115996.

24 Ibid. 
the Broadcasting Act and Telecommunications Act. ${ }^{25}$ The consultation had revealed there was a strong appetite within the traditional Canadian culture lobby for bringing policies such as cultural taxes and mandated Canadian content requirements to the Internet, with groups claiming the Internet was rapidly replacing the conventional broadcast system as a means of distributing cultural content and that the longstanding analog rules should be shifted into the digital environment. Revisiting Canada's twin communications laws was regarded by the cultural lobby as the opening to treat telecommunications regulation as a matter of cultural policy in what would amount to the Broadcasting Act taking over the Telecommunications Act.

In order to support the upcoming review of the Broadcasting Act and Telecommunications Act, the government asked the CRTC to become involved in developing policy. Through an Order-in-Council the government requested that the CRTC conduct a study on programming distribution models and their impact on maintaining a "vibrant domestic market." 26 The Commission was asked to address three main issues in its report: (1) the distribution model or models of programming that were likely to exist in the future; (2) how and through whom Canadians would access that programming and (3) the extent to which those models would ensure a vibrant domestic market capable of supporting the continued creation, production and distribution of Canadian programming, in both official languages, including original entertainment and information programming.

Joly formally unveiled her digital Canadian content strategy in September 2017, delivering a wide ranging plan that included a commitment from Netflix to spend $\$ 500$ million over five years on production in Canada. ${ }^{27}$ The Netflix commitment was the headline of the day, and represented a major long-term commitment to the Canadian market. However, since Canada was already one of the company's top three countries for pro-

25 Michael Geist, "Budget 2017: Why Canada's Digital Policy Future Is Up For Grabs,” Michael Geist (blog), March 22, 2017, https://www.michaelgeist.ca/2017/0 3/budget-2017-canadas-digital-policy-future-grabs/.

26 Canadian Radio-television and Telecommunications Commission, Broadcasting Notice of Consultation CRTC 2017-359, (Ottawa: Canadian Radio-television and Telecommunications Commission, 2017), https://crtc.gc.ca/eng/archive/2017/201 7-359.htm.

27 Canadian Heritage, Minister Joly Announces Creative Canada: A Vision for Canada's Creative Industries in the Digital Age (Ottawa: Canadian Heritage, 2017), https://ww w.canada.ca/en/canadian-heritage/news/2017/09/minister_joly_announcescreative canadaavisionforcanadascreativein.html. 
duction, it was unlikely the announcement would result in a significant increase in funding.

While the Netflix commitment attracted attention, the more important story was that the government had rejected pressures to levy new Internet or Netflix taxes, impose regulatory requirements on Internet services, or depart from its commitment to net neutrality. Indeed, Joly's comments on the importance of affordable Internet access and support for net neutrality effectively slammed the door shut on those proposals. Joly started the consultation by indicating that everything was on the table, which many cultural lobby groups hoped would lead to new Internet taxes and regulation. The decision to reject those proposals confirmed that the government's digital focus emphasized competition, a strong domestic market, as well as export and promotion of Canadian content.

\section{Chapter 4. A Shift in Approach: Harnessing Change}

The government's approach to regulating online video providers began to change after the release of the CRTC's report on programming distribution. In June 2018, the Commission released "Harnessing Change: The Future of Programming Distribution in Canada", ${ }^{28}$ in which it jumped into the Internet regulation and taxation game with both feet. Work that had preceded the Commission's report, including Joly's Digital Cancon strategy $^{29}$ as well as the Commission's own Let's Talk TV report ${ }^{30}$ had emphasized the benefits of the Internet and sided primarily with an exportoriented, competition focused strategy in which Canadian content and broadcasters would succeed based on the quality of their programming, not regulatory schemes designed to provide millions of dollars in support.

In Harnessing Change, the CRTC reversed that approach with a regulation-first strategy that envisioned new fees attached to virtually anything

28 Canadian Radio-television and Telecommunications Commission, Harnessing Change: The Future of Programming Distribution in Canada (Ottawa: Canadian Radio-television and Telecommunications Commission, 2018), https://crtc.gc.ca/e ng/publications/s15/.

29 Daniel Leblanc, "Everything's on the table," Globe and Mail, April 23, 2016, https://www.theglobeandmail.com/news/national/exclusive-canadian-heritage-ann ounces-sweeping-canconreview/article29722581/.

30 Canada Radio-television and Telecommunications Commission, Let's Talk TV: A Conversation with Canadians (Ottawa: Canadian-Radio-television and Telecommunications Commission, 2018), https:/crtc.gc.ca/eng/talktv-parlonstele.htm. 
related to the Internet: Internet service providers, Internet video services, and Internet audio services (wherever located) to name a few. The CRTC's report was provided to the government, but was accompanied by the feeling of theatre, with a review of telecom and broadcast legislation set to get underway that was to be led by a panel that included several proponents of an Internet regulation strategy.

Following the CRTC's report, the Minister of Innovation, Science and Economic Development tasked the Broadcasting and Telecommunications Legislative Review (BTLR) panel with a review of Canada's communications legislative framework. ${ }^{31}$ In September 2018, the panel opened a call for comments, through which industry stakeholders, civil society, academics and individuals provided their perspectives on the future of Canada's Broadcasting and Telecommunications acts. When the consultation closed in January 2019 thousands of submissions had been made. ${ }^{32}$ In June 2019, when the interim report was released alongside the written submissions, it began to look increasingly likely that the government had already decided what direction it intended to take. ${ }^{33}$

Canadian Heritage Minister Pablo Rodriguez, who had taken over the file from Joly, signalled that the government's position on the major broadcasting and Canadian cultural issue was already set. For months, government officials had been arguing that large Internet companies needed to contribute to Canadian content creation, though it had avoided specifying precisely how. With an election weeks away, the government position seemed to be shifting. Soon after the release of the BTLR interim report, Rodriguez tweeted that the government was ready to legislate once receiving the panel's final recommendations, but followed the statement by saying that "[e]veryone has to contribute to our culture. That's why

31 Innovation, Science and Economic Development Canada and Canadian Heritage, Government of Canada launches review of Telecommunications and Broadcasting Acts (Ottawa: Canadian Heritage, 2018), https:/www.canada.ca/en/canadian-heritage/ news/2018/06/government-of-canada-launches-review-of-telecommunications-and -broadcasting-acts.html.

32 Michael Geist, "Sunlight on the Submissions: Why the Broadcasting and Telecommunications Legislative Review Panel Should Reverse Its Secretive Approach," Michael Geist (blog), January 18, 2019, https://www.michaelgeist.ca/2019 /01/sunlight-on-the-submissions-why-the-btlr-should-reverse-its-secretive-approach /.

33 Innovation, Science and Economic Development Canada, What we Heard Report (Ottawa: Canada-Radio-television and Telecommunications Commission, 2019), http://www.ic.gc.ca/eic/site/110.nsf/eng/00011.html\#s8 
we'll require web giants to create Canadian content and promote it on their platforms." 34

By suggesting that the Liberals were ready to commit to legislative reform that would require Internet companies to create and promote Canadian content, the government had seemingly shifted its policy approach well ahead of the final BTLR report.

Chapter 5. BTLR report

In January 2020, the Broadcast and Telecommunications Legislative Review Panel released its much anticipated report with a vision of a highly regulated Internet in which an expanded CRTC (or a renamed Canadian Communications Commission) would aggressively assert its jurisdictional power over Internet sites and services worldwide with the power to levy penalties for failure to comply with its regulatory edicts. ${ }^{35}$

The foundation of the content section of the report was the decision to regulate all media content, which includes audio, audiovisual, and news content delivered by telecom. In doing so, the report envisioned unprecedented government and regulatory intervention into the delivery of news services. It argued that there are three types of services that provide this content that require regulation where they access the Canadian market:

- Curators - services that disseminate media content with editorial control (broadcasters and streaming services such as Netflix, Spotify, and Amazon Prime)

- Aggregators - cable companies, news aggregators such as Yahoo News

- Platforms for Sharing - services that allow users to share amateur and professional content such as YouTube, Facebook and other platforms

The panel recommended that all of these kinds of companies be regulated (either by way of licence or registration), be required to contribute to Canadian content through spending percentages or levies, and comply

34 Pablo Rodriguez (@pablorodriguez), “Thanks to @JanetYale1 \& panel for their work. We will be ready to legislate once we receive their recommendations," Twitter, June 26, 2019, 11:38 a.m., https://twitter.com/pablorodriguez/status/1143 906301002620928.

35 Canada, Broadcasting and Telecommunications Legislative Review, Canada's Communications Future: Time to Act (Ottawa: Innovation, Science and Economic Development Canada, 2020), https://www.ic.gc.ca/eic/site/110.nsf/vwapj/BTLR_E ng-V3.pdf/\$file/BTLR_Eng-V3.pdf. 
with CRTC regulations on discoverability that would include regulatory rules on how prominently Canadian content is displayed within the service. The CRTC would be empowered to decide whether to exempt services from regulation with the power to levy penalties for failure to comply with its decisions (penalties described as "high enough to create a deterrent foreign undertakings").

Services would also be required to disclose consumption data to the CRTC, so that the regulator would know what Canadians are watching or reading online. The regulator would be entitled to establish binding codes of conduct that cover resolution mechanisms, transparency, privacy and accessibility. It would also govern the commercial relationship between services and content producers, with the panel noting "it is essential that the CRTC be given the explicit jurisdiction to regulate the economic relationships between media content undertakings and content producers, as well as between media content undertakings." 36

The basis for the most sweeping reforms were framed as a matter of cultural sovereignty, with the panel arguing for the need for Canada "to continue to assert its cultural sovereignty and for Canadians to continue to express their identity and culture through content." 37 However, at a press conference following the report's release, both chair Janet Yale and panelist Monique Simard instead emphasized the need to support Canadian jobs when asked to reconcile the industry data that confirms record amounts of film and television production in Canada. ${ }^{38}$

Alternatively, the panel argued that it was simply a matter of those that benefit from the "system", being required to contribute to it. ${ }^{39}$ However, broadcasters and broadcast distributors already enjoyed a wide range of regulatory benefits in the system and their contributions were essentially a regulatory quid pro quo.

With respect to Canadian content, the panel acknowledged that "Canadians create and consume more types of content than ever before," indicat-

36 Broadcasting and Telecommunications Legislative Review, Canada's Communications, 144.

37 Ibid. at 117.

38 Headline Politics, "Broadcasting \& Telecommunications Legislative Review Panel Releases Final Report,” CPAC, January 29, 2020, https:/www.youtube.com/watch ? $\mathrm{v}=\mathrm{pYNpa04S4C0}$

39 Tony Wong, "Netflix should pay sales taxes, CBC should be ad free, communications panel recommends," Toronto Star, January 30, 2020, thestar.com/entertainm ent/2020/01/29/netflix-and-other-online-streaming-sites-must-contribute-to-canadi an-culture-and-content-says-legislative-review-panel.html. 
ing that its recommendations weren't about incentivizing the creation of Canadian content. ${ }^{40}$ Rather, the report seemed focused on certain professions creating content and imposing a massive regulatory infrastructure in order to support that policy goal. The problem with this approach was that ticking the right boxes to ensure Canadians represent "key creative personnel" had little to do with Canadian cultural sovereignty, much less ensuring access to Canadian stories. Yet while the panel emphasized "the importance of story", when confronted with the question of whether current Canadian content rules achieve that objective, it stated "it is time to review the model for supporting Canadian content, but not the definition of Canadian content." 41 The panel was prepared to overhaul the regulatory rules for creating and delivering Canadian content, but not consider the rules that determine what qualifies as Canadian content.

\section{Chapter 6. The Government Responds to the Yale Report: Bill C-10}

Taking up the recommendations from the BTLR panel report, in November 2020 Canadian Heritage Minister Steven Guilbeault tabled an Internet regulation bill with the express aim to "get money from web giants". ${ }^{42}$ As expected, Bill C-10 handed massive new powers to the CRTC to regulate online streaming services and opens the door to mandated Canadian content payments, discoverability requirements, and confidential information disclosures all backed by new fining powers. Given that many of the details will be sorted out by the CRTC, the specifics would have taken years to unfold had the bill become law.

\section{Chapter 7. Responding to a fictional content crisis}

In part, Bill C-10 responded to a fictional Canadian content "crisis." Canadian cultural lobby groups regularly claim that the sector is at risk. ${ }^{43}$ Yet

40 Canada, Broadcasting and Telecommunications Legislative Review, Canada's Communications Future, 117.

41 Ibid.

42 As of August 2021, the bill had been passed by the House of Commons, but was subject to review within the Canadian Senate. With a national election call, the bill died on the order paper and may only be re-introduced by a new government.

43 "Bill on Broadcasting Act: CDCE welcomes the decisive changes for our cultural sovereignty," CDCE, November 3, 2020, https://cdec-cdce.org/en/publications/r 
the reality is that spending on film and television production in Canada was at record highs. This included both certified Canadian content and so-called foreign location and service production in which the production takes place in Canada (thereby facilitating significant economic benefits) but does not meet the narrow criteria to qualify as "Canadian." The overall financing picture showed an industry that had record amounts of investment in film and television production with the total amount nearly doubling over the prior decade. Further, certified Cancon had also grown in recent years, with the top two years for certified Cancon television production occurring over the prior three years. In fact, 2019 was the biggest year for the production of French language Cancon over the prior decade. ${ }^{44}$

The data at the provincial level provided further confirmation of recordsetting production. In February 2020, Ontario Creates, the Government of Ontario's agency for cultural creation, touted a "record breaking year" for Ontario's film and television production sector, citing more than \$2 billion in production spending for 343 productions. ${ }^{45}$ Of the $\$ 2.1$ billion, there was a near-even split between domestic and foreign production: $\$ 1.1$ billion in foreign production and $\$ 1$ billion on domestic productions. In further support, Carleton professor Dwayne Winseck's 2020 review of the state of the network economy in Canada also found that film and television production investment in Canada had continuously increased for two decades, most recently "driven by massive investments from streaming services such as Netflix and Amazon Prime." 46 Politicians and regulators knew this to be the case. In fact, CRTC chair Ian Scott described Netflix as "probably the biggest single contributor to the [Canadian] production

elease-bill-on-broadcasting-act/; Maxime-Pierre Gazeau, "Bill C-10 to Extend the Broadcasting Act to Webcasters," Artisti, November 11, 2020, https://www.artisti.c a/en/bill-c-10-to-extend-the-broadcasting-act-to-webcasters/.

44 CMPA, Profile 2019: Economic Report on the Screen-Based Media Production Industry in Canada, (Ottawa: CMPA, 2019), Exhibit 1-1, Pg. 7, https://cmpa.ca/wp-content/ uploads/2020/04/CMPA_2019_E_FINAL.pdf.

45 Michael Geist, "Ontario's Record Breaking, Multi-Billion Dollar Film Production Year: 'A Healthy Balance Between Domestic and Foreign Production'," Michael Geist (blog), March 4, 2020, https://www.michaelgeist.ca/2020/03/ontarios-record -breaking-multi-billion-dollar-film-production-year-a-healthy-balance-between-do mestic-and-foreign-production/.

46 Winseck, Dwayne, Growth and Upheaval in the Network Media Economy in Canada, 1984-2019, (Ottawa, Canadian Media Concentration Research Project, Carleton University, 2020), 45, http://www.cmcrp.org/wp-content/uploads/2020/11/Growt h-Report-2020-11162020v2.pdf. 
sector today." ${ }^{47}$ Further, at the press conference introducing the bill, Guilbeault acknowledged that the Internet companies are already investing in Canada, but argued that the bill was needed to ensure those investments were not voluntary. ${ }^{48}$

Chapter 8. The myth of the level playing field

A central part of Guilbeault's argument for Bill C-10 was that it levels the playing field between traditional and online broadcasters. It is true that conventional broadcasters and broadcast distributors face mandated payments to support Canadian content as part of their licensing requirements. Leaving aside the fact that broadcasters were seeking reductions in payments at the CRTC, ${ }^{49}$ the notion that the only regulatory burden or benefit is mandated Cancon contributions misreads the law. The reality is that broadcasters receive benefits worth hundreds of millions of dollars in return for those payments as part of what amounts to a regulatory quid pro quo. None of those benefits are available to Internet streaming services, yet the "level the playing field" discussion focused exclusively on equivalent payment requirements.

Some of the regulatory and policy benefits enjoyed by traditional broadcasters and broadcast distributors not available to Internet streaming services included:

1. Simultaneous Substitution Policies, which allow Canadian broadcasters to replace foreign signals with their own. The industry says this policy alone generates hundreds of millions of dollars in revenues for

47 Terry Pedwell, "Streaming companies like Netflix will have to fund Canadian content: CRTC chair," National Post, January 8, 2020, https://nationalpost.com/p $\mathrm{mn} /$ news-pmn/canada-news-pmn/streaming-companies-like-netflix-will-have-to-fu nd-canadian-content-crtc-chair.

48 "Heritage minister discusses bill to update Broadcasting Act - November 3, 2020," CPAC, 2020, YouTube Video, https://www.youtube.com/watch?v=qkV $1 \mathrm{Wp} 4 \mathrm{JduU}$.

49 Canadian Radio-television and Telecommunications Commission, Broadcasting Notice of Consultation CRTC 2020-336 (Ottawa: Canadian Radio-television and Telecommunications Commission, 2020), https://crtc.gc.ca/eng/archive/2020/202 0-336.htm. 
Canadian broadcasters. ${ }^{50}$ There is no equivalent to the hundreds of millions generated by this policy for Internet streaming services.

2. Must-Carry Regulations, which require broadcast distributors to include many Canadian channels on basic cable and satellite packages. ${ }^{51}$ These rules provide guaranteed access to millions of subscribers, thereby increasing the value of the signals and the fees that can be charged for their distribution. Internet streamers compete for subscribers with no guaranteed access.

3. Copyright Retransmission Rules, which create an exemption in the Copyright Act to allow broadcast distributors to retransmit signals without infringing copyright. ${ }^{52}$ This retransmission occurred for many years without any compensation. There is no equivalent for Internet streamers.

4. Bundling Benefits, which allow broadcast distributors to bundle less popular Canadian channels with more popular U.S. signals, thereby guaranteeing more revenues to the Canadian broadcasters. ${ }^{53}$ There is no equivalent for Internet streamers.

5. Market Protection, which shielded Canadian broadcasters from foreign competition such as HBO or ESPN for decades. ${ }^{54}$ Internet streamers compete for subscribers with no market protections and the prospect of users unsubscribing at any time.

6. Foreign Investment Restrictions, which limits the percentage that foreign companies may own of Canadian broadcasters or broadcast distributors, which has the effect of creating a protected marketplace with reduced competition.

50 Christine Dobby, "Bell launches new appeal of CRTC's Super Bowl ad policy," The Globe and Mail, December 28, 2016, https:/www.theglobeandmail.com/repor t-on-business/nfl-hopes-trudeau-government-will-overturn-crtc-super-bowl-ad-ruli ng/article33442315/.

51 Michael Geist, "The Broadcasting Act Blunder, Day 2: What the Government Doesn't Say About Creating a 'Level Playing Field'," Michael Geist (blog), November 20, 2020, https://www.michaelgeist.ca/2020/11/the-broadcasting-act-blunder-d ay-two-what-the-government-doesnt-say-about-creating-a-level-playing-field/\#: :tex $\mathrm{t}=$ Simultaneous\%20Substitution\%20policies\%2C\%20which\%20allows\%20Canadi an $\% 20$ broadcasters $\% 20$ to, millions $\% 20$ of $\% 20$ dollars $\% 20$ in $\% 20$ revenues $\% 20$ for $\% 2$ 0Canadian\%20broadcasters.

52 Ibid.

53 Ibid.

54 Ibid. 
7. Eligibility for Canadian Funding Programs, which are available to Canadian entities to support content creation but may be unavailable to foreign entities such as the Internet streamers. ${ }^{55}$

8. Unlimited Distribution Without Caps or Usage Charges, unlike Internet-based services, whose subscribers often face high data costs for accessing those services.

9. Intellectual Property Preferences, which requires that producers be Canadian in order to be certified as Cancon..$^{56}$ This leads to rules that preclude foreign companies from producing Cancon and requiring domestic IP ownership. As a result, Internet streamers are excluded from accessing the same funding available to Canadian producers.

10. Trade Agreement Protections, which exempt the Canadian government from treating foreign providers in the culture sector in the same manner as domestic firms. ${ }^{57}$ While this provision is subject to potential tariff retaliation (as will be discussed later in the series), it means that standard practices regarding equal treatment do not apply to Internet streamers.

\section{Chapter 9. Missing economic thresholds}

Guilbeault also tried to assure the House of Commons that the bill featured several "guardrails" against over-broad regulation. In particular, he stated that online entities would need to reach an economic threshold before being subject to any regulation. ${ }^{58}$ However, there was no specific economic threshold established by the bill. The starting point was that all Internet streaming services carried on in whole or in part within Canada are subject to Canadian regulation.

Guilbeault was presumably referring to the fact that section 6(4) of the bill gave the CRTC the power to exempt services from regulation. ${ }^{59}$

55 Ibid.

56 Ibid.

57 Ibid.

58 Guilbeault, Steven, House of Commons Debates Canada (Ottawa: House of Commons, 2020), https://www.ourcommons.ca/DocumentViewer/en/43-2/house/sittin g-31/hansard, Para 1640.

59 House of Commons of Canada, An Act to amend the Broadcasting Act and to make consequential amendments to other Acts, Bill C-10, 2nd sess, introduced in House November 3, 2020, https://www.parl.ca/LegisInfo/BillDetails.aspx?Language=E\&b illId $=10926636$. 
While the CRTC could certainly establish some thresholds for regulation following the enactment of the bill, the approval of a policy directive, and a full hearing on the implementation issues, the possibility that the CRTC could create thresholds is not the same as claiming that the law contains significant economic thresholds. In fact, it is likely that the CRTC would not limit the regulatory model to "companies that generate large revenues in Canada", whatever that means. In order for the CRTC to determine who might be exempt, it was likely to require even smaller foreign services to register with the regulator and to provide it with confidential subscriber and revenue data.

The uncertainty of who is caught by the regulation was sure to have an impact on the market. Internet streaming services thinking about the Canadian market might put those plans on hold until they have some visibility over what they face from a regulatory perspective, leading to less competition and less choice for Canadians. Should the CRTC establish an economic threshold, that too could have an unexpected impact. If it set a high threshold that is limited to a handful of large, U.S.-based streaming services, it invited the possibility of a trade challenge. If a low threshold becomes the standard, foreign services may avoid the Canadian market altogether given the regulatory costs.

\section{Chapter 10. Removing Canadian ownership requirements}

One of the more controversial aspects of Bill C-10 proved to be the decision to remove the very first policy declaration in the Broadcasting Act as found in Section 3(1)(a): "the Canadian broadcasting system shall be effectively owned and controlled by Canadians." For years, Canada has prioritized a Canadian broadcast system with Canadian ownership requirements and Canadian content rules. With Bill C-10, the government signalled that it believed the benefits that come from mandatory contributions from foreign companies (bearing in mind that the companies voluntarily invest in the market) were worth sacrificing the longstanding policy of keeping the Canadian system Canadian.

(4) The Commission shall, by order, on the terms and conditions that it considers appropriate, exempt persons who carry on broadcasting undertakings of any class specified in the order from any or all of the requirements of this Part, of an order made under section 9.1 or of a regulation made under this Part if the Commission is satisfied that compliance with those requirements will not contribute in a material manner to the implementation of the broadcasting policy set out in subsection 3(1). 
Guilbeault was asked about the ownership during the first day of House of Commons debate on the bill. He responded that the amendment to section 3(1) was necessary in order to allow the government to collect money from "web giants". ${ }^{60}$ Guilbeault was right that Canada cannot have it both ways. It cannot argue that foreign companies must be part of - and contribute to - the Canadian system and then also argue that the system must be owned and controlled by Canadians. Either foreign companies are part of the system or they are not.

Guilbeault' proposed solution was to remove the policy of Canadian ownership and control, but use licensing to ensure that Canadian companies retain that same control. Indeed, many countries have removed foreign ownership requirements given the lack of a link between domestic content requirements and domestic ownership. Guilbeault therefore said the removal of Section 3(1)(a) was immaterial since licensing requirements would still apply to broadcasters and could be used to ensure that they remain in Canadian hands. Yet the obvious trajectory of the new Canadian system is to shift away from that licensing system. The government claimed it is creating a level playing field, but broadcasters in the licensed world would increasingly look at the unlicensed Internet world that is free from foreign investment restrictions and conclude that they prefer the unlicensed system.

The issue could become particularly acute if Canadian broadcasters are forced to compete with companies like Netflix and Disney for Canadian content as all participants race to meet their regulatory Cancon requirements. The disadvantages of remaining Canadian-owned would become increasingly apparent as more broadcasters surrender their licences in favour of switching to streaming-only services that remain unlicensed and have the advantage of no foreign ownership limitations. The Canadian market would feature an increasingly prominent foreign ownership presence, not only in the form of foreign streamers but also Canadian-originated streamers that become foreign-controlled through new investment.

\section{Chapter 11. Discoverability requirements}

Among the issues that Bill C-10 was intended to remedy, Guilbeault cited the need to improve the "discoverability" of Canadian content. Under section 9.1(1) the Bill permits the CRTC to make orders, including those

60 Canada, House of Commons Debates, Para 1645. 
with respect to program presentation and discoverability. The term "discoverability" does not appear elsewhere in the bill and is not defined. It would therefore fall to the CRTC to decide what it means and what conditions are imposed on Internet services as a result. Based on the Canadian cultural debate of the past few years, it would be expected that the CRTC would be urged to require services such as Netflix or Disney+ to override their algorithms that identify what subscribers are likely to want to see by actively promoting Canadian content regardless of their preferred content.

The BTLR panel, which recommended discoverability regulations, went looking for evidence of a discoverability problem and found very little. That report identified just two sources: a 2017 PriceWaterhouseCoopers report ${ }^{61}$ and a 2016 report from Telefilm Canada. ${ }^{62}$ The PriceWaterhouseCoopers report involved a survey of 1,000 U.S. residents, had nothing to do with Canada, and said absolutely nothing about the ability to find or recognize Canadian content. The Telefilm Canada report was focused on Canada but did not find that Canadians have trouble finding Canadian content. Rather, it found a range of experiences and emphasized that "word-of-mouth is Canadians' main discoverability method." Two reports - one from the U.S. and the other four years old - do not make the case for new regulations requiring the CRTC to regulate the way online services make their content available to subscribers in Canada.

\section{Chapter 12. Downgrading the Role of Canadians in their Own Programming}

One of the benefits of Bill C-10 touted by Guilbeault was that it was a big win for Canadian creators. Section 3(1)(f) of the current Broadcasting Act features the policy on use of Canadian creative talent, saying that "each broadcasting undertaking shall make maximum use, and in no case less than predominant use, of Canadian creative and other resources in the creation

61 Mark McCaffrey, Paige Hayes and Jason Wagner, Can you find that show I didn't know I wanted to watch?: How tech will transform content discovery, (London: PriceWaterhouseCoopers, 2017) https:/gsma.force.com/mwcoem/servlet/servlet.FileD ownload?file=00P1r00001kQ5tHEAS

62 The Telefilm Canada report is incorrectly cited as a 2018 report but actually dates to 2016:

Telefilm Canada, Discoverability: Toward a Common Frame of Reference: Part 2: The Audience Journey, (Montreal: Telefilm Canada, 2016) https://telefilm.ca/en/studies/ discoverability-toward-common-frame-reference-part-2-audience-journey. 
and presentation of programming". Bill C-10 dropped the expectation of maximum or predominant use. The policy provision instead would state:

each broadcasting undertaking shall make use of Canadian creative and other resources in the creation and presentation of programming to the extent that is appropriate for the nature of the undertaking

No one knew what that means since it would fall to the CRTC to determine what is "appropriate given the nature of the undertaking". Presumably the change was needed given the expansive regulatory approach taken by Bill C-10. Since the bill effectively captured foreign streaming sites both big and small, news sites, and podcasters, the government apparently felt that it could no longer require predominantly Canadian creative talent or even meet "the greatest practicable use of those resources" standard.

\section{Chapter 13. The "Regulate Everything" Approach}

The government was careful to note that it was not creating a new licensing system for Internet services with Bill C-10. For example, the Canadian Heritage FAQ stated "Canadians will still be able to watch all of their favourite programs and access their preferred services. This Bill in no way prevents online streaming services from operating in Canada, or requires them to be licensed." 63

Bill C-10 was clear that in contrast to conventional broadcasters, online undertakings such as Internet streaming services would not require a licence to operate in Canada. While conventional broadcast undertakings (ie. programming undertakings) require either a licence or an exemption from the CRTC, online undertakings do not require either. Yet given the regulatory requirements, the absence of a licence would mean little for services operating in Canada, thinking about operating in Canada, or simply having Canadian users. For them, Bill C-10 provided a whole new regime that replaced licensing or exemption with "registration" subject to "conditions".

Bill C-10 created this new regime through amendments to sections 9, 10 and 11 of the Act. These new powers would allow the CRTC to:

63 Government of Canada, Frequently asked questions - Modernizing the Broadcasting Act for the Digital Age (Ottawa: Government of Canada, 2021), https://www.canad a.ca/en/canadian-heritage/services/modernization-broadcasting-act/faq.html. 
- require registration of any broadcasting undertaking (section 10(1)(i))

- impose, by order, conditions that are virtually indistinguishable from licensing requirements (s.9.1(1))

- implement a wide range of additional regulations (sections 10 and 11).

Section 10(1)(i) gave the CRTC the power to establish regulations that could require all broadcasting undertakings - including online undertakings - to register with the Commission. Given how broadly the bill defined the jurisdictional scope, this included smaller streaming services, video news sites, podcasters, or even user generated content sites that include anything other than user generated content. Unless the CRTC decided to establish new thresholds or exemptions, all of these sites and services were caught by the bill and subject to Canada's new registration requirement.

The regulatory power extended beyond registration requirements, however. The CRTC could establish registration fees (the bill limited the fees to the costs incurred by the Commission) as well as regulations on Canadian programming, advertising rules, and audit rules that would have allowed the CRTC to examine records and books of any registered entity. These were all regulations that specifically could have been targeted at online undertakings such as Internet-based services. To be clear, failure to comply with these regulations carried the possibility of stiff penalties. ${ }^{64}$

Further, Section 34.4 established the possibility of administrative monetary penalties (AMPs) for contravening these regulations that ran into the millions of dollars. So while the government argued that it was not licensing Internet services, it created a regulation system that included registration, mandated audits, and Cancon conditions all backed by millions in potential penalties for failure to comply.

But Bill C-10 went beyond those regulatory requirements. Section 9.1 (1) featured numerous conditions that could have been imposed on any broadcast undertaking - including online undertakings. In addition the aforementioned discoverability conditions, the CRTC could have imposed conditions related to:

64 House of Commons of Canada, An Act to amend the Broadcasting Act, s.33.

Section 33 provides: Every person who contravenes any regulation or order made under this Part is guilty of an offence punishable on summary conviction and is liable (a) in the case of an individual, to a fine of not more than \$25,000 for a first offence and of not more than \$50,000 for each subsequent offence; or $(b)$ in the case of a corporation, to a fine of not more than $\$ 250,000$ for a first offence and of not more than $\$ 500,000$ for each subsequent offence. 
- the proportion of programs to be broadcast that are Canadian

- access by persons with disabilities to programming, including the identification, prevention and removal of barriers to such access

- the carriage of emergency messages

- providing the CRTC with information on ownership, governance and control of the services as well as any affiliates

- providing the CRTC with any other information it requires, including financial or commercial information, programming information, expenditure information, and any information related to the provision of broadcasting services

While these provisions may fit within a licensed, Canadian-only environment, the conditions could have been applied by the CRTC to foreign online services with no presence in Canada. In fact, without any economic thresholds in the bill, the starting point was that all services around the world were potentially covered by these conditions so long as they have some Canadian subscribers. The CRTC may have ultimately limited the reach of the rules following extensive hearings, but for services thinking about the Canadian market, the regulatory environment might well have been reason to block Canadian subscribers. Guilbeault claimed that Bill C-10 would not result in less consumer choice, yet the more likely outcome was a Canadian regulatory firewall that had new entrant streaming services thinking twice before entering the market.

While the CRTC would have been tasked with establishing the specifics, the bill was also notable in that it granted the Commission the power to target individual services or companies with unique or individualized requirements. In other words, rather than establishing a "level playing field", Guilbeault opened the door to multiple fields with individual companies potentially each facing their own specific requirements and conditions to operate in Canada.

The source of this targeted approach was Section 9.1 (2), which provides:

(2) An order made under this section may be made applicable to all persons carrying on broadcasting undertakings, to all persons carrying on broadcasting undertakings of any class established by the Commission in the order or to a particular person carrying on a broadcasting undertaking. ${ }^{65}$

65 House of Commons of Canada, An Act to amend the Broadcasting Act, s. 9.1 (2). 
The regulatory ability to single out individual services for specific conditions (as opposed to common rules for all) created significant regulatory uncertainty, invited the possibility of a trade challenge, could have sparked allegations of unfair treatment, and raised further doubts for potential entrants into the Canadian market. The government claimed that consumer choice would not be affected by Bill C-10, but the likely repercussions of its legislative proposal strongly suggested otherwise.

\section{Chapter 14. Risk to Canadian Ownership of Intellectual Property}

At a time when the government emphasized the importance of intellectual property, the bill opened the door to less Canadian control and ownership over its IP. There was no reference to intellectual property in the bill nor any discussion of it within Canadian Heritage's FAQ or departmental materials. ${ }^{66}$ Other than a background document reference to IP that suggested it could be included in a policy direction to the CRTC, intellectual property was not prioritized in the bill. In fact, by mandating that foreign services pay to support Canadian content and claiming they should be treated as equivalent to Canadian services for regulatory purposes, the government placed policy measures designed to safeguard intellectual property at risk.

IP policy has long been viewed as an important part of Canadian content policy. A production can be certified as Canadian content either through access to tax credits and/or Canadian Media Fund subsidy, or by the CRTC. All three require Canadian ownership of IP. For example, tax credits favour Canadian copyright ownership with larger credits available under the Canadian Film or Video Production Tax Credit (which requires Canadian copyright ownership) than with Film or Video Production Services Tax Credit (which does not).

These policies have prioritized domestic IP ownership and precluded foreign companies from producing and owning fully-financed Canadian content. As a result, revivals of Canadian programs such as Trailer Park Boys (Netflix) or Kids in the Hall (Amazon) would not meet the qualification requirements as Cancon where those companies are the sole funders and producers. The problem with Bill C-10 was that since no production fully-financed and owned by a foreign entity can be certified as Canadian content and the government sought to mandate such financing, the Canadian content rules would have had to change. If those changes meant 
removing the IP ownership link between tax credits and subsidies, and well-financed foreign streamers were allowed to fully-finance and own Canadian content, they could easily outbid Canadian producers for the best content. The end result could be that the best Canadian IP is owned by foreign streaming services, not Canadians.

\section{Chapter 15. Mandated Confidential Data Disclosures May Keep Companies Out of Canada}

Bill C-10 established significant confidential data disclosure requirements as a condition that could be imposed on Internet services both big and small around the world.

Section 9.1(1)(j) gave the CRTC the power to set a requirement on all broadcast undertakings, including online undertakings, to provide information the Commission considered necessary for the administration of the Act ${ }^{67}$, including:

I. financial or commercial information,

II. information related to programming,

III. information related to expenditures made under section 11.1,

IV. information related to audience measurement, other than information that could identify any individual audience member, and

$\mathrm{V}$. other information related to the provision of broadcasting services

In other words, the CRTC could demand everything: financial data, programming data, expenditure information, audience measurement data, and anything else it deemed relevant. In many cases, this information is commercially sensitive, not publicly available, and not required by other regulators.

While the CRTC needs good data to make effective decisions, the broad approach to mandated confidential information disclosure carried some significant risks. As noted previously, the condition on information disclosure could be limited to specific companies. For example, the CRTC could require companies such as Netflix or YouTube to disclose detailed audience and algorithmic data, which is data that those companies have been reluctant to make available anywhere in the world.

Moreover, the disclosure requirements were likely to extend to a very broad range of services, many of which may have limited or little connec-

67 House of Commons of Canada, An Act to amend the Broadcasting Act, 9.1(1)(j). 
tion to Canada. While the bill did not contain economic thresholds the CRTC could establish such thresholds after extensive hearings. If it did so, companies could have been required to provide the Commission with confidential subscribers and financial data as evidence that they qualify for an exemption. In other words, services of all sizes and from all over the world would find themselves caught by CRTC regulation and requirements to disclose their confidential data. Their response may well have been to give Canada a pass by actively blocking Canadian users to reduce the risk of regulation, thereby leaving consumers with less choice and competition.

\section{Chapter 16. Mandated Payments Likely to Bring in Less Than the Government Claims}

Guilbeault made mandated payments the centrepiece of his Bill C-10 strategy, claiming that this would result in a billion dollars a year by 2023 in new funding. ${ }^{68}$ The mandatory payment system was established in Section 11.1(1) of the bill and left it open to the CRTC to decide precisely who contributes, how they contribute, and how much they contribute.

Yet despite the fact that the CRTC would determine actual amounts, Guilbeault still clearly had a number in mind given the claims of $\$ 1$ billion in new revenues. In fact, the number was $\$ 830$ million when the bill was launched, ${ }^{69}$ but the Minister was soon claiming nearly a billion instead. ${ }^{70}$ In fact, Guilbeault went even further in the House, suggesting "it is actually more than $\$ 1$ billion, because if nothing is done by 2023 , Canadian productions and Canadian artists will miss out on $\$ 1$ billion." 71

The claim appears to simply represent a rough estimate on Canadians revenues from services such as Netflix with mandated payments of about 30 percent of those revenues. In the case of Netflix, its publicly stated revenues for Canada in 2019 were $\$ 780$ million in revenue during the first 9 months, ${ }^{72}$ so about $\$ 975$ million for the year. At 30 percent, Netflix contribution would be around $\$ 293$ million or about 30 percent of Guil-

68 Canada, House of Commons Debates, para 1650.

69 Government of Canada, Frequently asked questions.

70 Canada, House of Commons Debates, para 1625.

71 Ibid., para 1650.

72 Kelly Townsend, "Netflix has earned $\$ 780 \mathrm{M}$ in Canadian revenue in 2019," Playback, December 17, 2019, https://playbackonline.ca/2019/12/17/netflix-has-earned $-780 \mathrm{~m}$-in-canadian-revenue-in-2019/. 
beault's projected billion dollars in 2023, a number that could grow as revenues climb.

That will sound tempting to many, but it isn't the entire story. In the case of Netflix, it committed in 2017 to spend $\$ 500$ million on productions in Canada over the following five years. ${ }^{73}$ One year later, the company said it was on track to exceed that commitment. ${ }^{74}$ In other words, Netflix was already spending hundreds of millions of dollars on production in Canada. While it is uncertain how the CRTC would mandate spending, it seems likely that the lion share of spending would be re-allocated money, not new funding. The same would apply to many other services that are already producing in Canada with money being reallocated to meet the regulatory requirements. To suggest that this will mean one billion dollars per year in new funding is at best a stretch.

\section{Chapter 17. Misleading Comparison to the European Union}

Guilbeault regularly cited the situation in Europe as evidence that the concerns about how Bill C-10 was likely to increase costs for consumers and decrease choice were unfounded. For example, he told the House of Commons that "European Union has adopted new rules on streamers resulting in increased investment, jobs, choice of content and ability to assert one's own cultural sovereignty" 75 and told the media that the European Union has had a requirement since 2018 that 30\% of Internet streaming services content must be European content without resulting in higher fees. ${ }^{76}$

Guilbeault's comparison of Bill C-10 to the situation in Europe was misleading at best. A closer look reveals that after 10 years of regulatory work, less than a handful of EU member states have actually implemented

73 Catherine Cullen, "Netflix to commit $\$ 500 \mathrm{M}$ over 5 years on new Canadian productions: sources," CBC News, September 27, 2017, https://www.cbc.ca/news/p olitics/netflix-canadian-content-broadcaster-1.4309381\#: :text=Politics-,Netflix\%2 0to\%20commit $\% 20 \% 24500 \mathrm{M} \% 20$ over\%205\%20years\%20on\%20new,productions \%2C\%20CBC\%20News\%20has\%20learned.

74 Corie Wright, “A Busy First Year for Netflix Canada," Netflix, September 28, 2018, https://about.netflix.com/en/news/a-busy-first-year-for-netflix-canada.

75 Canada, House of Commons Debates, para 1635.

76 Alex Boutilier, "Liberals propose law forcing Netflix, Spotify and others to support Canadian content," The Star, November 3, 2020, https:/www.thestar.com/po litics/federal/2020/11/03/liberals-propose-law-forcing-netflix-spotify-and-others-to-s upport-canadian-content.html. 
the rules. Those that have done so have opted for much lower obligations with payment requirements that are a fraction of what Guilbeault had in mind. Moreover, scale matters and attempts to compare quotas intended for a market of 450 million people and 28 countries to a single country of 38 million is apples and oranges.

The European Audiovisual Media Services Directive was passed by the EU Parliament and Council in November $2018^{77}$ and features at least four elements that bear some similarity at first glance to Bill C-10:

1. The designation of social media platforms as video-sharing platforms. This bring companies like Facebook, Instagram, and YouTube into the same regulatory sphere as Netflix, Apple TV, Amazon Prime and other streaming sites.

2. The imposition of the obligation for all Video on Demand (VOD) services (i.e.: streaming services) to have at least $30 \%$ of their catalogue be European works. This means all streaming services operating across European countries must have at least $30 \%$ of their country-specific catalogue be European.

3. The $30 \%$ obligation is accompanied by a prominence requirement which mandates all VOD services to have an EU works section on their platform so European films and movies are easily discoverable by users.

4. The directive provides each member state the ability to require VOD service providers to invest in EU works. These funding requirements can be applied to service providers targeting audiences in a member state even when they are under the jurisdiction of another member state.

In other words, the directive includes content and discoverability requirements, but does not mandate a funding requirement. In that regard, it is different from Bill C-10, which emphasized funding over content requirements.

While Guilbeault suggested that the European directive has not had a negative effect on consumers, the reality is that few member states have actually implemented it despite an obligation to do so by September $2020 .{ }^{78}$ In fact, even those that have implemented the directive have adopt-

77 Audiovisual and Media Services Directive, European Commission (2021), https:// ec.europa.eu/digital-single-market/en/audiovisual-media-services-directive-avmsd.

78 Glenn Carstens Peters, "Member States fail to meet the Audiovisual Media Services Directive deadline," Society of Audiovisual Authors (blog), September 17, 2020, https://www.saa-authors.eu/en/blog/667-member-states-fail-to-meet-the-audi ovisual-media-services-directive-deadline\#.YGe2SmRKg3R. 
ed differing approaches. For example, countries such as the Netherlands, Croatia, Poland, and Denmark have investment quotas of under 6\%, a far cry from the $30 \%$ envisioned by Guilbeault. ${ }^{79}$ Meanwhile, Germany is still debating the levy and Spain is thinking about a 5\% requirement. ${ }^{80}$ The overall approach to date suggests that the $30 \%$ payment requirement is dramatically out-of-step with what is found in Europe. Given the far higher payment requirements in Canada, the consumer implications would undoubtedly be far greater.

The content requirements are also an inapt comparison to Canada. The 30\% requirement covers European content, not content from a single country. Given the size of the European market and the number of member states, the actual per country requirement is effectively just over 1\% if divided evenly among the member states. The reality is that services will surely exceed that number locally since it is in their interests to do so in order to attract local customers. However, any attempt to compare a $30 \%$ requirement that draws on a population of approximately 450 million people and 28 member states with Canada just doesn't work.

Finally, consider how long the process in Europe has taken (and continues to take). While Guilbeault talked about a regulatory process concluding by the end of 2021, Europe has taken more than ten years to develop its rules and the majority of member states still have not implemented them at a domestic level. The European experience highlights that these are complex issues that require careful study, not a "trust us" approach that leaves most of the key issues to a policy directive or the regulator.

\section{Chapter 18. Bill C-10 and the Regulation of User Generated Content}

The public paid little attention to Bill C-10 for months after it was introduced. Indeed, by late April 2021, the bill had steadily and stealthily worked its way through the Parliamentary process with only a few hurdles left to clear before passing the House of Commons. However, the bill was suddenly thrust onto the front page of newspapers across the country toward the end of its review journey with the public seizing on an

79 Nick Vivarelli, "Europe's New Rules of Engagement With Streaming Making Slow But Steady Progress”, Variety, March 5, 2021, https://variety.com/2021/digita 1/news/europe-avms-streamers-1234915013/.

80 Ibid. 
unexpected change that opened the door to government regulation of the Internet content posted by millions of Canadians.

The change involved the removal of a clause that exempted from regulation user generated content on social media services such as TikTok, Youtube, and Facebook. The government had maintained that it had no interest in regulating user generated content, but the policy reversal meant that millions of video, podcasts, and the other audiovisual content on those popular services would be treated as "programs" under Canadian law and subject to some of the same rules as those previously reserved for programming on conventional broadcast services. Indeed, when Guilbeault appeared before the Standing Committee on Canadian Heritage he was asked by Liberal MP Tim Louis about "misinformation that somehow this [Bill C-10] would control, or regulate, or censor social media." He responded:

In the case of YouTube, for example, we're not particularly interested in what people...you know, when my great-uncle posts pictures of his cats, that's not what we're interested in as a legislator. When YouTube or Facebook act as a broadcaster, then the legislation would apply to them and the CRTC would define how that would happen. But really, we're not interested in user-generated content. We are interested in what broadcasters are doing. ${ }^{81}$

Guilbeault was referring to a specific exception in Bill C-10 that excluded user generated content from the scope of broadcast regulation. The provision stated:

This Act does not apply in respect of

(a) programs that are uploaded to an online undertaking that provides a social media service by a user of the service - who is not the provider of the service or the provider's affiliate, or the agent or mandatary of either of them - for transmission over the Internet and reception by other users of the service; and

(b) online undertakings whose broadcasting consists only of such programs. 82

81 Parliament, House of Commons, Canadian Heritage Committee, Minutes of Proceedings 43rd Parliament, Meeting No 18 (Ottawa: Parliament, House of Commons, Canadian Heritage Committee, 2021), https://openparliament.ca/committees/can adian-heritage/43-2/18/steven-guilbeault-10/.

82 House of Commons of Canada, An Act to amend the Broadcasting Act, s.4.1. 
Without this provision, anything uploaded by users - whether cat videos or kids dancing in the kitchen - would be treated by Canadian law as a "program" and subject to CRTC regulation. In fact, government officials confirmed that interpretation:

Ms. Dabrusin has signalled the government intends to repeal, or suggest a repeal, of Section 4.1 altogether, meaning that there would no longer be any exclusion for social media services at all. For the benefit of the committee, in our previous sessions, the committee upheld the exclusion for users of social media companies. In other words, when you or I upload something to YouTube or some other sharing service, we will not be considered broadcasters for the purposes of the Act. The CRTC couldn't call us before them and we couldn't be subject to CRTC hearings.

But if the exclusion is removed - if 4.1 is struck down - the programming we upload to Youtube, that programming that we place on that service would be subject to regulation moving forward, but would be the responsibility of Youtube or whatever the sharing service is. The programming that is uploaded could be subject to discoverability requirements or certain obligations like that. If the way forward is to maintain the exclusion for individual users but to strike down the exclusion for social media companies, that means that all the programming that is on those services would be subject to the Act regardless of whether it was put there by an affiliate or a mandatary of the company. ${ }^{83}$

The change in approach sparked widespread public concern with the main opposition party vowing to repeal the legislation if enacted. The government's initial response to the controversy focused on two issues: the constitutionality of the change and attempts to limit regulatory power over user generated content to data disclosures by Internet services and the previously discussed discoverability requirements.

With respect to compliance with the Canadian Charter of Rights and Freedoms, the government provided an updated Charter statement which shed little light on the concerns involving the regulation of user generated content as a "program" under the law, however. Instead, it simply emphasized that users are not regulated as broadcasters and the CRTC is required to rule in a manner consistent with the Charter.

83 ParlVu, "CHPC Meeting No. 26 - Standing Committee on Canadian Heritage," ParlVu, April 23, 2021, https://parlvu.parl.gc.ca/Harmony/en/PowerBrowser/Powe rBrowserV2/20210423/-1/35243. 
The government also sought to justify the broader regulatory scope by pointing to the need for discoverability requirements for user generated content. Yet that too faced public criticism. First, as noted above, there was little evidence supporting claims of a problem in discovering Canadian content. Second, beyond the ease with which Canadian content can be found on audio and video-on-demand services, critics noted no other country mandates domestic content requirements on a user generated content platforms. That includes the European Union approach, which explicitly treats audiovisual media services (such as Netflix) and video sharing platform services (such as Youtube) differently. Audiovisual media services that engage in curating content face content requirements similar to those found for conventional broadcasters. Video sharing platform services face rules with respect to removing certain illegal or harmful content, but there are no quotas or no positive obligations to prioritize some content over others.

\section{Chapter 19. The Bill C-10 Endgame}

Faced with ongoing opposition in the House of Commons and lengthy debates and delays during review of Bill C-10, the government ultimately joined forces with two smaller opposition parties to impose a process known as "time allocation", which limited the time available for further study to five hours. The process, which had not been used in more than twenty years for a committee study, was highly controversial with many noting that it tainted the legitimacy of the review process.

The committee was forced to comply with the time allocation order, however, leading to a rapid conclusion to the study of Bill C-10 with Members of Parliament voting on dozens of amendments that were not made public at the time nor subject to any debate. Yet days later, the Speaker of the House of Commons declared many amendments "null and void", forcing the government to re-introduce the amendments within the House of Commons. In order to pass the amendments and bring the debate on Bill C-10 to a close, the government passed multiple motions to cut short debate and ultimately passed the bill in the middle of the night when few Canadians were still awake. ${ }^{84}$

84 House of Commons Canada, Vote No. 174 (Ottawa: House of Commons, 2021), https://www.ourcommons.ca/members/en/votes/43/2/174. 
With only days remaining before the summer recess, the bill was sent to the Senate for review. The Senate Bill C-10 debate wrapped up with several speeches and a vote to send the bill to committee for further study. Given that the Senate declined to approve summer hearings for the bill, with the earliest possible time for the study to begin in late September 2021. Yet with the late summer election call, Bill C-10 died on the order paper before the Senate study could begin in earnest.

While the debate in the Senate was marked by consistent calls for more study, the final debate was punctuated by a powerful speech from Senator David Adams Richards. One of Canada's leading authors, Senator Richards has won the Governor General's Award for both fiction and non-fiction, the Giller Prize, and is a member of the Order of Canada. Senator Richards, appointed by Prime Minister Trudeau to the Senate in 2017, warns against government or cultural decision makers and the parallels to Bill C-10:

Some years ago, I was at a dinner with some very important, famous people. One academic mentioned that he had given his entire life for Canadian literature. Others there applauded him for doing so. When I was writing my fourth novel, we sold our 20-year-old car to pay the rent; and my wife, to keep us alive, was selling Amway door-to-door in the middle of winter. I believe she gave her life for Canadian literature as well, but she didn't get to that dinner. For that reason, in her honour, I will always and forever stand against any bill that subjects freedom of expression to the doldrums of governmental oversight, and I implore others to do the same. I don't think this bill needs amendments; I think, however, it needs a stake through the heart. ${ }^{85}$

After months of Canadian Heritage Minister Steven Guilbeault invoking the names of cultural lobby groups as evidence of support for Bill C-10, it took one of Canada's most celebrated authors to set the record straight and bring the debate to a close. In doing so, Senator Richards placed the spotlight on the challenges of reshaping Canada's broadcasting laws and difficulty in striking a balance between modernized Internet rules and freedom of expression safeguards.

85 Senator David Adams Richards, Senate Hansard, Senators' Statements (Ottawa: Senate of Canada, 2021), https://sencanada.ca/en/content/sen/chamber/432/debate s/056db_2021-06-29-e\#35. 


\section{Bibliography}

Audiovisual and Media Services Directive, European Commission (2021). https://ec .europa.eu/digital-single-market/en/audiovisual-media-services-directive-avmsd.

Bibic, Mirko. Transcript of Proceedings. Quebec: Canadian Radio-Television and Telecommunications Commission, 2009. https://crtc.gc.ca/eng/transcripts/2009/ tb0311.html.

Bill C-10. An Act to amend the Broadcasting Act and to make consequential amendments to other Acts. 2nd sess. 43rd Parliament. 2020. https://www.parl.ca/LegisInf o/BillDetails.aspx?Language=E\&billId=10926636.

Boutilier, Alex. "Liberals propose law forcing Netflix, Spotify and others to support Canadian content.” The Star. November 3, 2020. https://www.thestar.com/politi cs/federal/2020/11/03/liberals-propose-law-forcing-netflix-spotify-and-others-to-su pport-canadian-content.html.

Canada. Broadcasting and Telecommunications Legislative Review. Canada's Communications Future: Time to Act. Ottawa: Innovation, Science and Economic Development Canada, 2020. https://www.ic.gc.ca/eic/site/110.nsf/vwapj/BTLR_ Eng-V3.pdf/\$file/BTLR_Eng-V3.pdf.

Canada. Canadian Radio-television and Telecommunications Commission. Harnessing Change: The Future of Programming Distribution in Canada. Ottawa: Canadian Radio-television and Telecommunications Commission, 2018. https://crtc.g c.ca/eng/publications/s15/.

Guilbeault, Steven. House of Commons Debates. Ottawa: House of Common Debates, 2020. https://www.ourcommons.ca/DocumentViewer/en/43-2/house/sittin g-31/hansard.

Canadian Heritage, Minister Joly Announces Creative Canada: A Vision for Canada's Creative Industries in the Digital Age. Ottawa: Canadian Heritage, 2017. https://w ww.canada.ca/en/canadian-heritage/news/2017/09/minister_joly_announcescreat ivecanadaavisionforcanadascreativein.html.

Canada. Parliament. House of Commons. Canadian Heritage Committee. Minutes of Proceedings. 2nd sess. 43rd Parliament. Meeting No. 18, 2021. https://openparli ament.ca/committees/canadian-heritage/43-2/18/steven-guilbeault-10/.

Canadian Radio-television and Telecommunications Commission. Broadcasting Notice of Consultation CRTC 2020-336. Ottawa: Canadian Radio-television and Telecommunications Commission, 2020. https://crtc.gc.ca/eng/archive/2020/ 2020-336.htm.

Canadian Radio-television and Telecommunications Commission. Broadcasting and Telecom Notice of Consultation CRTC 2011-344. Ottawa: Canadian Radio television and Telecommunications Commission, 2011. https:/crtc.gc.ca/eng/archive/ 2011/2011-344.pdf.

Canadian Radio-television and Telecommunications Commission. Broadcasting Regulatory Policy CRTC 2009-329. Ottawa: Canadian Radio-television and Telecommunications Commission, 2009. https://crtc.gc.ca/eng/archive/2009/ 2009-329.pdf. 
Canadian Radio-television and Telecommunications Commission. Broadcasting Notice of Consultation CRTC 2017-359. Ottawa: Canadian Radio-television and Telecommunications Commission, 2017. https://crtc.gc.ca/eng/archive/2017/ 2017-359.htm.

Canadian Radio-television and Telecommunications Commission. Public Notice CRTC 1998-82 - New Media - Call for Comments. Ottawa: Canadian Radio-television and Telecommunications Commission, 1998. https://crtc.gc.ca/eng/archive/ 1998/PB98-82.htm.

Canadian Radio-television and Telecommunications Commission. Public Notice CRTC 1999-84 - Report on New Media. Ottawa: Canadian Radio-television and Telecommunications Commission, 1998. https://crtc.gc.ca/eng/archive/1999/PB 99-84.htm

Canadian Radio-television and Telecommunications Commission. Transcript of Proceedings. Ottawa: Canadian Radio-Television and Telecommunications Commission, 2009. https://crtc.gc.ca/eng/transcripts/2009/tb0226.htm.

Canadian Radio-television and Telecommunications Commission. Transcript of Proceedings. Ottawa: Canadian Radio-Television and Telecommunications Commission, 2009. https://crtc.gc.ca/eng/transcripts/2009/tb0310.html. https:/crtc.gc.ca/ eng/archive/1999/PB99-84.htm.

CMPA. Profile 2019: Economic Report on the Screen-Based Media Production Industry in Canada. Ottawa: CMPA, 2019. https://cmpa.ca/wp-content/uploads/2020/04/ CMPA_2019_E_FINAL.pdf.

Crull, Kevin. Transcript of Proceedings. Quebec: Canadian Radio-Television and Telecommunications Commission, 2011. https://crtc.gc.ca/eng/transcripts/2011/ tb0404.html.

Cullen, Catherine. "Netflix to commit $\$ 500 \mathrm{~m}$ over 5 years on new Canadian productions: sources.” CBC News, September 27, 2017. https://www.cbc.ca/news /politics/netflix-canadian-content-broadcaster-1.4309381\#: :text=Politics-,Netflix \%20to\%20commit $\% 20 \% 24500 \mathrm{M} \% 20$ over\%205\%20years\%20on\%20new,product ions $\% 2 \mathrm{C} \% 20 \mathrm{CBC} \% 20 \mathrm{News} \% 20$ has\%20learned.

Department of Canadian Heritage. Canadian Content in a Digital World: Focusing the Conversation. Ottawa: Department of Canadian Heritage, 2016. https://www. canadiancontentconsultations.ca/system/documents/attachments/e328d01aaa5d 8b25b5b2e769f0f3ccb59f63893e/000/004/022/original/PCH-DigiCanCon-Consu ltation_Paper.pdf.

Dobby, Christine. "Bell launches new appeal of CRTC's Super Bowl ad Policy." The Globe and Mail, December 28, 2016. https://www.theglobeandmail.com/rep ort-on-business/nfl-hopes-trudeau-government-will-overturn-crtc-super-bowl-ad-r uling/article33442315/.

Gazeau, Maxime-Pierre. "Bill C-10 to Extend the Broadcasting Act to Webcasters." Artisti, November 11, 2020. https:/www.artisti.ca/en/bill-c-10-to-extend-the-broa dcasting-act-to-webcasters/.

Geist, Michael. "Budget 2017: Why Canada's Digital Policy Future is Up For Grabs.” Michael Geist (blog). March 22, 2017. https://www.michaelgeist.ca/2017/ 03/budget-2017-canadas-digital-policy-future-grabs/. 
Geist, Michael. “Ontario’s Record Breaking, Multi-Billion Dollar Film Production Year: 'A Healthy Balance Between Domestic and Foreign Production'.” Michael Geist (blog). March 4, 2020. https://www.michaelgeist.ca/2020/03/ontarios-recor d-breaking-multi-billion-dollar-film-production-year-a-healthy-balance-between -domestic-and-foreign-production/.

Geist, Michael. "Sunlight on the Submissions: Why the Broadcasting and Telecommunications Legislative Review Panel Should Reverse Its Secretive Approach.” Michael Geist (blog). January 18, 2018. https:/www.michaelgeist.ca/2019/01/sunl ight-on-the-submissions-why-the-btlr-should-reverse-its-secretive-approach/.

Geist, Michael. "The Broadcasting Act Blunder, Day 2: What the Government Doesn't Say About Creating a 'Level Playing Field'." Michael Geist (blog). November 20, 2020. https:/www.michaelgeist.ca/2020/11/the-broadcasting -act-blunder-day-two-what-the-government-doesnt-say-about-creating-a-level-play ing-field/\#: :text=Simultaneous\%20Substitution\%20policies\%2C\%20which\%20 allows $\% 20$ Canadian $\% 20$ broadcasters $\% 20$ to,millions $\% 20$ of $\% 20$ dollars $\% 20$ in $\% 20$ revenues\%20for\%20Canadian\%20broadcasters.

"GST on Netflix still a possibility as Liberals review cultural production." CTV News, October 16, 2016. https://www.ctvnews.ca/politics/gst-on-netflix-still-a-pos sibility-as-liberals-review-cultural-production-1.3115996.

Government of Canada. Frequently asked questions - Modernizing the Broadcasting Act for the Digital Age. Ottawa: Government of Canada, 2021. https://www.canad a.ca/en/canadian-heritage/services/modernization-broadcasting-act/faq.html.

Headline Politics. "Broadcasting \& Telecommunications Legislative Review Panel Releases Final Report.” CPAC. January 29, 2020. https://www.cpac.ca/en/progra $\mathrm{ms} /$ headline-politics/episodes/66143249/\#.

"Heritage minister discusses bill to update Broadcasting Act - November 3, 2020." CPAC. 2020. YouTube Video. https://www.youtube.com/watch?v=qkV1Wp4Jdu U.

House of Commons of Canada. An Act to amend the Broadcasting Act and to make consequential amendments to other Acts, Bill C-10. Ottawa: House of Commons of Canada, 2020. https://www.parl.ca/LegisInfo/BillDetails.aspx?Language=E\&billI $\mathrm{d}=10926636$.

Innovation, Science and Economic Development Canada and Canadian Heritage. Government of Canada launches review of Telecommunications and Broadcasting Acts. Ottawa: Canadian Heritage, 2018. https:/www.canada.ca/en/canadian-herit age/news/2018/06/government-of-canada-launches-review-of-telecommunication s-and-broadcasting-acts.html.

Ipsos. What we heard across Canada: Canadian Culture in a Digital World. Ottawa: Ipsos Public Affairs, 2017. https:/www.canadiancontentconsultations.ca/system/ documents/attachments/7fbdb8859168fdacec048735532bfdf6c45789a0/000/005/ 630/original/PCH-DigiCanCon-Consultation_Report-EN_low.pdf

McCaffrey, Mark, Hayes, Paige and Jason Wagner. Can you find that show I didn't know I wanted to watch? How tech will transform content discovery. London: PriceWaterhouseCoopers, 2017. https://gsma.force.com/mwcoem/servlet/servlet.File Download?file=00P1r00001kQ5tHEAS. 
ParlVu. "CHPC Meeting No. 26 - Standing Committee on Canadian Heritage." ParlVu. April 23, 2021. https://parlvu.parl.gc.ca/Harmony/en/PowerBrowser/Po werBrowserV2/20210423/-1/35243.

Pedwell, Terry. "Streaming companies like Netflix will have to fund Canadian content: CRTC chair.” National Post. January 8, 2020. https://nationalpost.com/p $\mathrm{mn} /$ news-pmn/canada-news-pmn/streaming-companies-like-netflix-will-have-to-f und-canadian-content-crtc-chair.

Peters, Glenn Carstens. "Member States fail to meet the Audiovisual Media Services Directive deadline." Society of Audiovisual Authors (blog). September 17, 2020. https://www.saa-authors.eu/en/blog/667-member-states-fail-to-meet-the-au diovisual-media-services-directive-deadline\#.YGe2SmRKg3R.

Robertsen, Paul. Transcript of Proceedings. Quebec: Canadian Radio-Television and Telecommunications Commission, 2011. https://crtc.gc.ca/eng/transcripts/2011/ tb0604.html.

Rodriguez, Pablo (@pablorodriguez). “Thanks to @JanetYale1 \& panel for their work. We will be ready to legislate once we receive their recommendations." Twitter. June 26, 2019. 11:38 a.m. https://twitter.com/pablorodriguez/status/114 3906301002620928.

Senator David Adams Richards, Senate Hansard. Senators' Statements. Ottawa: Senate of Canada, 2021, https://sencanada.ca/en/content/sen/chamber/432/debat es/056db_2021-06-29-e\#35Telefilm Canada. Discoverability: Toward a Common Frame of Reference: Part 2: The Audience Journey. Montreal: Telefilm Canada, 2016. https:/telefilm.ca/en/studies/discoverability-toward-common-frame-refere nce-part-2-audience-journey.

Townsend, Kelly. "Netflix has earned \$780M in Canadian revenue in 2019." Playback. December 17, 2019. https://playbackonline.ca/2019/12/17/netflix-has-earne d-780m-in-canadian-revenue-in-2019/.

Vivarelli, Nick. "Europe's New Rules of Engagement With Streaming Making Slow But Steady Progress”, Variety, March 5, 2021, https://variety.com/2021/digital/ne ws/europe-avms-streamers-1234915013/.

Winseck, Dwayne. Growth and Upheaval in the Network Media Economy in Canada, 1984-2019. Ottawa: Canadian Media Concentration Research Project, Carleton University, 2020. http://www.cmcrp.org/wp-content/uploads/2020/11/Growth-R eport-2020-11162020v2.pdf.

Write, Corie. “A Busy First Year for Netflix Canada.” Netflix. September 28, 2018. https://about.netflix.com/en/news/a-busy-first-year-for-netflix-canada. 
